LWSA

PAPER - OPEN ACCESS

Kedudukan Upah dan Hak-Hak Lain Pekerja Pada Perusahaan Pailit Pasca Putusan Mahkamah Konstitusi Nomor 67/PUU$\mathrm{XI} / 2-13$

\author{
Author $\quad:$ Adeline Laureen Turangan \\ DOI $\quad: 10.32734 /$ lwsa.v1i1.157 \\ Electronic ISSN : :2654-7058 \\ Print ISSN : :2654-7066
}

Volume 1 Issue 1 - 2018 TALENTA Conference Series: Local Wisdom, Social and Arts

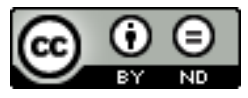

This work is licensed under a Creative Commons Attribution-NoDerivatives 4.0 International License.

Published under licence by TALENTA Publisher, Universitas Sumatera Utara
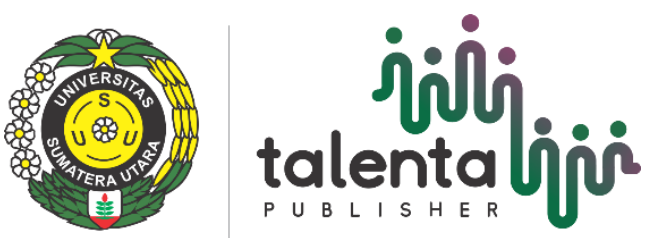


\title{
Kedudukan Upah dan Hak-Hak Lain Pekerja Pada Perusahaan Pailit Pasca Putusan Mahkamah Konstitusi Nomor 67/PUU-XI/2-13
}

\author{
Adeline Laureen Turangan ${ }^{\mathrm{a}}$; Agusmidah ${ }^{\mathrm{a}}$; Suria Ningsih ${ }^{\mathrm{a}}$
}

\begin{abstract}
Abstrak
UU Ketengakerjaan No. 13 Tahun 2003 menetapkan bahwa dalam keadaan perusahaan dinyatakan pailit maka kedudukan upah pekerja/buruh tidak didahulukan sebelum kreditor separatis, pembayaran utang pajak, penggantian polis asuransi dan hak tanggungan. Hal ini dapat menghilangkan hak pekerja/buruh untuk memperoleh upah dan hakhak pasca hubungan kerja (pesangon, uang penghargaan masa kerja, penggantian hak). Penelitian ini merupakan penelitian hukum normatif dengan pendekatan perundang-undangan. Hasil penelitian mengungkapkan bahwa setelah adanya Putusan Mahkamah Konstitusi Nomor 67/PUU-XI/2013 upah pekerja atau buruh harus didahulukan. Sehingga harusnya apabila suatu perusahaan diputuskan pailit, maka perusahaan tersebut terlebih dahulu membayar hak upah pekerja atau buruhnya yang terutang, meski kedudukan hak-hak lain pekerja atau buruh masih berada di bawah tagihan hak upah dan kreditur separatis.
\end{abstract}

Kata Kunci: Upah; Pailit; Ketenagakerjaan; Putusan MK Nomor 67/PUU-XI/2013.

\section{Latar Belakang}

Upah merupakan organ penting sebagai imbalan dan penghargaan dari hasil pencapaian kerja seorang buruh. Seorang buruh berhak untuk mendapatkan imbalan dan perlakuan yang adil dan layak dalam hubungan kerja, untuk menciptakan serta menjaga kesejahteraannya serta anggota keluarganya. Sistem pengupahan merupakan kerangka bagaimana upah diatur dan ditetapkan. Sistem pengupahan di Indonesia pada umumnya dibentuk berdasarkan kepada fungsi dasar upah, yaitu menjamin kehidupan yang layak bagi pekerja dan keluarganya, mencerminkan imbalan atas hasil kerja seseorang, dan menyediakan insentif untuk mendorong peningkatan produktivitas kerja (Suryahadi dkk, 2003).

Kepailitan merupakan suatu proses di mana seorang debitur yang mempunyai kesulitan keuangan untuk membayar utangnya dinyatakan pailit oleh pengadilan, dalam hal ini adalah pengadilan niaga, dikarenakan debitur tersebut tidak dapat membayar utangnya, Harta debitur dapat dibagikan kepada para kreditur sesuai dengan peraturan perundangan yang berlaku. Tidak dapat dipungkiri bahwasannya setiap perusahaan berpeluang mengalami pailit.

Perusahaan yang dinyatakan pailit atau dilikuidasi berdasarkan peraturan perundang-undangan yang berlaku, maka upah dan hak-hak lainnya dari pekerja/buruh merupakan utang yang didahulukan pembayarannya (UU No. 13 Tahun 2003 tentang Ketenagakerjaan), namun pada prakteknya dalam pembayaran utang pailit, upah buruh kerap berada dalam posisi yang lemah dan tidak sejajar dengan kreditur separatis. Karena pembayaran utang kreditur separatis cenderung lebih diutamakan.

Hal tersebut menggerakkan buruh Pertamina mengajukan pengujian materi terhadap pasal 95 (4) Undang-undang Ketenagakerjaan untuk klausula —didahulukann pembayarannyall agar lebih diperjelas dan dipertegas. Hasil uji materi 
itu menghasilkan Putusan Mahkamah Konstitusi Nomor 67/PUU-XI/2013. Menjadi permasalah yang akan dibahas dalam paper ini adalah bagaimana kedudukan upah dan hak-hak lain pekerja atau buruh sebelum dan sesudah putusan Mahkamah Konstitusi Nomor 67/PUU-XI/2013 dalam perusahaan pailit. Pemecahan masalah dilakukan dengan menelaah norma-norma hukum dalam peraturan perundang-undangan yang berlaku (yuridis normatif) dengan demikian dilakukan pendekatan perundang-undangan (Statue Appraoch) (Peter Mahmud Marzuki, 2005).

\section{Pembahasan}

\subsection{Upah dan Pailit}

Setiap orang memiliki hak untuk hidup dan selalu berusaha memenuhi segala kebutuhan dalam hidupnya, sehingga setiap orang membutuhkan pekerjaan untuk mendapatkan upah agar dapat membiayai serta meningkatkan derajat hidup pekerja atau buruh dan keluarganya. Dalam hubungan kerja, upah merupakan hak dasar bagi seorang pekerja atau buruh. Upah merupakan organ penting sebagai imbalan dan penghargaan dari hasil pencapaian kerja seorang buruh di dalam suatu perusahaan. Keharmonisan antara pengusaha dengan pekerja atau buruh dapat menciptakan kepuasan dari kedua pihak, pekerja atau buruh harus berusaha memaksimalkan jalannya pekerjaan, sehingga dapat menghasilkan produksi yang maksimal yang membawa perusahaan pada keuntungan yang diharapkan oleh pengusaha atau pemberi kerja. Besar kecilnya upah maka diperlukan negosiasi yang setara dan terbuka antara pengusaha dan pekerja berdasarkan data dan fakta yang ada. Dalam konteks ini maka serikat pekerja hendaknya mampu melaksanakan peran mediator berlandaskan data-data atau analisis ilmiah bukan pada sesuatu yang bersifat emosional. Negosiasi yang didasarkan pada emosi akan menghasilkan lost-lost solution dan ini justri akan memperparah situasi sosial kemasyarakatan dalam skala luas (Prijono Tjiptoherijanto, 2003).

Dalam berdirinya suatu Perusahaan tidak selalu dihadapkan pada laba, tetapi ada masa dimana perusahaan mengalami kerugian. Maka tidak dapat dipungkiri bahwa setiap perusahaan berpeluang mengalami Pailit. Pailit adalah keadaan dimana seorang Debitor tidak mampu membayar utang yang dimilikinya walaupun telah ditagih karena jatuh tempo. Kepailitan adalah sita umum atas semua kekayaan Debitor Pailit yang pengurusan dan pemberesannya dilakukan oleh Kurator di bawah pengawasan Hakim Pengawas sebagaimana diatur dalam Undang-undang ini (UU No. 37 Tahun 2004 tentang Kepailitan dan Penundaan Kewajiban).

Pasal 2 Undang-Undang No. 37 Tahun 2004 menyebutkan syarat kepailitan. Debitor yang mempunyai dua atau lebih Kreditor dan tidak membayar lunas sedikitnya satu utang yang telah jatuh waktu dan dapat ditagih, dinyatakan pailit dengan putusan Pengadilan, baik atas permohonnya sendiri maupun atas permohonan satu atau lebih kreditornya (Pasal 2 ayat(1).

Unsur yang menjadi syarat-syarat kepailitan yaitu: adanya utang. Utang adalah kewajiban yang dinyatakan atau dapat dinyatakan dalam jumlah uang baik dalam mata uang Indonesia maupun mata uang asing, baik secara langsung maupun yang akan timbul dikemudian hari atau kontijen, yang timbutl karena perjanjian atau undang-undang dan yang wajib dipenuhi oleh Debitor dan bila tidak dipenuhi memberi hak kepada Kreditor untuk mendapat pemenuhannya dari harta kekayaan debitor (Pasal 1 ayat (6)).

Adanya dua kreditor. Ketentuan ini hanya memungkinkan seorang debitur dinyatakan pailit apabila debitur memiliki paling sedikit dua kreditur. Syarat mengenai adanya minimal dua atau lebih kreditur disebut dengan concursus creditorium.

Syarat debitur harus mempunyai lebih dari seorang kreditur ini selaras dengan ketentuan Pasal 1132 KUH Perdata yang menentukan pembagian secara teratur semua harta pailit kepada para krediturnya, yang dilakukan berdasarkan prinsip pari passu proprate parte. Adapun dalam hal ini yang dipersyaratkan bukan berapa besar piutang yang mesti ditagih oleh seorang kreditur dari debitur yang bersangkutan, melainkan berapa banyak orang yang menjadi kreditur dan debitur yang bersangkutan dan berapa banyak orang yang menjadi kreditur dan debitur yang bersangkutan.

Salah satu utang jatuh waktu dan dapat ditagih.Utang yang telah jatuh waktu dan dapat ditagih telah dirumuskan dalam Penjelasan Pasal 2 ayat (1) yaitu kewajiban untuk membayar utang yang telah jatuh waktu, baik karena telah diperjanjikan, karena percepatan waktu penagihannya sebagaimana diperjanjikan, karena pengenaan sanksi atau denda oleh instansi yang berwenang, maupun karena putusan pengadilan, arbiter, atau majelis arbitrase. Syarat bahwa utang 
harus telah jatuh waktu dan dapat ditagih menunjukkan bahwa kreditur sudah mempunyai hak untuk menuntut debitur untuk memenuhi prestasinya.

Hak-hak debitor untuk melakukan semua tindakan hukum yang berkenaan dengan kekayaannya harus di hormati, tetapi akibat hukum yang ditimbulkan dari pernyataan pailit mengakibatkan debitur yang dinyatakan pailit kehilangan segala bentuk hak perdata atas harta kekayaan yang telah masuk ke dalam harta pailit, debitur tidak lagi menguasai harta kekayaan. Akibat Kepailitan diatur dalam Bagian Kedua Undang-undang Kepailitan dan Penundaan Kewajiban Pembayaran Utang. Harta pailit meliputi seluruh Menurut Pasal 21 Undang-undang Kepailitan dan Penundaan Kewajiban Pembayaran Utang, kepailitan meliputi semua harta kekayaan debitur yang ada pada saat pernyataan pailit diucapkan serta semua kekayaan yang diperolehnya selama pailit.

Dari ketentuan Pasal 21 di atas diketahui bahwa kepailitan merupakan sita umum. Dengan adanya sita umum ini hendak dihindari adanya sita perorangan. Pembentuk Undang-undang memandang perlu untuk memungkinkan adanya eksekusi masal dengan cara melakuan sitaan umum atas seluruh harta kekayaan debitor untuk kepentingan semua kreditor yang bersangkutan yang dijalankan dengan pengawasan seorang Hakim Pengawas. Sita umum tersebut haruslah bersifat konservatoir yaitu bersifat penyimpanan bagi kepentingan semua kreditor yang bersangkutan.

Undang-undang memungkinkan dicabutnya kepailitan meskipun kepailitan tersebut sedang diproses di Pengadilan, jika keadaan harta pailit menghendakinya. Pengadilan, atas anjuran Hakim Pengawas dan, jika ada panitia para kreditur, setelah mendengar panitia tersebut, atau setelah mendengar atau setelah memanggil debitur, dapat memerintahkan agar kepailitan dicabut. Dalam hal ini, perintah pencabutan kepailitan tersebut harus dibuat dalam suatu penetapan Hakim, yang diucapkan dalam sidang terbuka untuk umum. Hakim yang memerintahkan pengakhiran pailit menetapkan jumlah biaya kepailitan dan imbalan jasa kurator, serta membebankannya kepada debitur. Biaya dan imbalan jasa tersebut memiliki hak mendahulu atas seluruh utang konkuren yang tidak dijamin dengan agunan.

\section{2. Kedudukan Upah dan Hak Normatif Pekerja Dalam Pailit}

Pasal 95 ayat (4) Undang-undang Ketenagakerjaan, dalam hal perusahaan dinyatakan pailit atau dilikuidasi berdasarkan peraturan perundang-undangan yang berlaku, maka upah dan hak-hak lainnya dari pekerja/buruh merupakan utang yang didahulukan pembayarannya. Ketika terjadi Pailit pembayaran upah pekerja/buruh dilakukan oleh Kurator yang dalam hal ini menggantikan posisi Perusahaan. Sehingga hak buruh dalam hal ini upah dan tunjangan lainnya menurut Undang-Undang Ketenagakerjaan akan berubah menjadi utang yang didahulukan pembayarannya dan penjelasannya menyebutkan yang dimaksud didahulukan pembayarannya adalah upah pekerja/buruh harus dibayar lebih dahulu daripada utang-utang lainnya. Dalam pasal 39 ayat (2) Undang-Undang No. 37 Tahun 2004 tentang Kepailitan dan Penundaan Kewajiban Pembayaran Utang telah ditentukan bahwa upah buruh untuk waktu sebelum dan sesudah pailit termasuk utang harta pailit artinya upah buruh harus dibayar lebih dahulu daripada utang-utang lainnya.

Melihat kenyataan ini, antara perlindungan hak pekerja dalam Undang-Undang Kepailitan dan UU Ketenagakerjaan terdapat perbedaan yang signifikan, di dalam Undang-Undang Kepailitan upah buruh untuk waktu sebelum dan sesudah pailit termasuk utang harta pailit artinya upah buruh harus dibayar lebih dahulu daripada utang-utang lainnya tetapi tidak jelas diatur utang yang lainnya ini utang yang mana dan bagaimana proses penyelesaiannya. Sementara dalam UU Ketenagakerjaan juga menyatakan hal yang sama yaitu Pasal 95 ayat (4), secara jelas dan gamblang menekankan bahwa upah dan hak-hak lainnya dari pekerja/buruh merupakan utang yang didahulukan pembayarannya untuk melindungi dan menjamin keberlangsungan hidup dan keluarganya.

Setelah diputuskan, karyawan maupun kurator memiliki hak untuk memutuskan hubungan kerja. Hak pekerja terbagi atas hak upah dan hak selain upah yang masih mencakup materi seperti pesangon. Hak upah pekerja termasuk dalam utang harta pailit, yang harus dibayarkan. Dan dalam pasal 165 UU Ketenagakerjaan disebutkan bahwa pengusaha dapat melakukan pemutusan hubungan kerja terhadap pekerja/ buruh karena perusahaan pailit, dengan ketentuan pekerja/buruh berhak atas uang pesangon sebesar 1 (satu) kali ketentuan Pasal 156 ayat (2), uang penghargaan masa kerja sebesar 1 (satu) kali ketentuan Pasal 156 ayat (3) dan uang penggantian hak sesuai ketentuan Pasal 156 ayat (4). 
Pasal 156 ayat (2) menyangkut ketentuan penghitungan uang pesangon: masa kerja kurang dari 1 (satu) tahun, 1 (satu) bulan upah;

1. masa kerja 1 (satu) tahun atau lebih tetapi kurang dari 2 (dua) tahun, 2 (dua) bulan upah;

2. masa kerja 2 (dua) tahun atau lebih tetapi kurang dari 3 (tiga) tahun, 3 (tiga) bulan upah;

3. masa kerja 3 (tiga) tahun atau lebih tetapi kurang dari 4 (empat) tahun, 4 (empat) bulan upah;

4. masa kerja 4 (empat) tahun atau lebih tetapi kurang dari 5 (lima) tahun, 5 (lima) bulan upah;

5. masa kerja 5 (lima) tahun atau lebih, tetapi kurang dari 6 (enam) tahun, 6 (enam) bulan upah;

6. masa kerja 6 (enam) tahun atau lebih tetapi kurang dari 7 (tujuh) tahun, 7 (tujuh) bulan upah.

7. masa kerja 7 (tujuh) tahun atau lebih tetapi kurang dari 8 (delapan) tahun, 8 (delapan) bulan upah;

8. masa kerja 8 (delapan) tahun atau lebih, 9 (sembilan) bulan upah.

Pasal 156 ayat (3) menyangkut ketentuan perhitungan uang penghargaan masa kerja, yaitu:

1. masa kerja 3 (tiga) tahun atau lebih tetapi kurang dari 6 (enam) tahun, 2 (dua) bulan upah;

2. masa kerja 6 (enam) tahun atau lebih tetapi kurang dari 9 (sembilan) tahun, 3 (tiga) bulan upah;

3. masa kerja 9 (sembilan) tahun atau lebih tetapi kurang dari 12 (dua belas) tahun, 4 (empat) bulan upah;

4. masa kerja 12 (dua belas) tahun atau lebih tetapi kurang dari 15 (lima belas) tahun, 5 (lima) bulan upah;

5. masa kerja 15 (lima belas) tahun atau lebih tetapi kurang dari 18 (delapan belas) tahun, 6 (enam) bulan upah;

6. masa kerja 18 (delapan belas) tahun atau lebih tetapi kurang dari 21 (dua puluh satu) tahun, 7 (tujuh) bulan upah;

7. masa kerja 21 (dua puluh satu) tahun atau lebih tetapi kurang dari 24 (dua puluh empat) tahun, 8 (delapan) bulan upah;

8. masa kerja 24 (dua puluh empat) tahun atau lebih, 10 (sepuluh) bulan upah.

Pasal 156 ayat (4) menyangkut ketentuan perhitungan uang penggantian hak, yaitu:

1. cuti tahunan yang belum diambil dan belum gugur;

2. biaya atau ongkos pulang untuk pekerja/buruh dan keluarganya ke tempat di mana pekerja/buruh diterima bekerja;

3. penggantian perumahan serta pengobatan dan perawatan ditetapkan $15 \%$ (lima belas perseratus) dari uang pesangon dan/atau uang penghargaan masa kerja bagi yang memenuhi syarat;

4. hal-hal lain yang ditetapkan dalam perjanjian kerja, peraturan perusahaan atau perjanjian kerja bersama.

Menurut Pasal 39 ayat (2) Undang-undang Kepailitan dan Penundaan Kewajiban Pembayaran Utang yang berisi: "Sejak tanggal putusan pernyataan pailit diucapkan, upah yang terutang sebelum maupun sesudah putusan pernyataan pailit diucapkan merupakan utang harta pailit." Kurator wajib mencatat dan mencantumkan daftar utang piutang harta pailit sebelum akhirnya di umumkan ke publik. Pembayaran upah kepada pekerja merupakan hal yang diutamakan meskipun pengusaha yang perusahaannya sedang menjalani sanksi pidana penjara, kurungan, dan/atau denda. Hal ini tertulis dalam pasal 189 Undang-undang Ketenagakerjaan.

Undang-undang Ketenagakerjaan tidak mengenal definisi hak-hak lainnya. Untuk mengetahui apa saja yang disebut hak-hak lainnya dari pekerja, harus dikorelasikan dengan pemutusan hubungan kerja (PHK). Ketika perusahaan diputus pailit, peristiwa yang lazim terjadi adalah PHK. Pekerja yang di PHK bukan karena melakukan kesalahan, sesuai UU Ketenagakerjaan, berhak memperoleh uang pesangon. Ketika pekerja di PHK, baik karena alasan pailit maupun alasan lainnya, uang pesangon dihitung secara normatif, berpedoman pada masa kerja, upah pokok, dan tunjangan tetap (KSBI,tthn). 
Ketentuan Pasal 95 ayat (4) UU Ketenagakerjaan memang mewajibkan perusahaan yang pailit harus mendahulukan pemenuhan hak-hak pekerja seperti pesongan dan hak-hak lainnya. Namun, dalam praktik, terdapat urutan peringkat penyelesaian tagihan kreditor setelah selesainya kreditor separatis, dimana upah buruh masih harus menunggu urutan setelah tagihan hak negara, kantor lelang, dan badan umum yang dibentuk Pemerintah untuk didahulukan.

Hak-hak normatif pekerja atau buruh pada perusahaan pailit tidak dijabarkan secara rinci ataupun khusus di dalam Undang-undang ketenagakerjaan. Penelusuran yang penulis lakukan mengacu pada Undang-undang Ketenagakerjaan yang hanya mengatur tentang upah dalam keadaan pailit karena pasal 95 ayat (4) diundangkan dalam Undang-undang Ketenagakerjaan pada bagian pengupahan.

Pada perusahaan dalam keadaan pailit, berlaku penggantian hak yang terjadi apabila perusahaan tersebut memutuskan hubungan kerja secara sepihak atas keterpaksaan pailit yang terkandung di dalam Pasal 62 yang berisi, sebagai berikut: "Apabila salah satu pihak mengakhiri hubungan kerja sebelum berakhirnya jangka waktu yang ditetapkan dalam perjanjian kerja waktu tertentu, atau berakhirnya hubungan kerja bukan karena ketentuan sebagaimana dimaksud dalam Pasal 61 ayat (1), pihak yang mengakhiri hubungan kerja diwajibkan membayar ganti rugi kepada pihak lainnya sebesar upah pekerja/buruh sampai batas waktu berakhirnya jangka waktu perjanjian kerja."

\subsection{Kedudukan Upah dan Hak Normatif Pekerja Dalam Pailit}

Upah adalah sebuah indikator harapan utama dari para buruh untuk memenuhi kebutuhan hidup pekerja atau buruh dan apabila melihat APBN sangat sedikit mengalokasikan untuk subsidi pekerja atau butuh. Hal ini disampaikan oleh Timboel Siregar, ia setuju bahwa pekerja atau buruh adalah kelompok menengah dan penghargaan atas pekerjaan yang mereka lakukan hanyalah sebatas upah.

Pemohon menilai pada praktiknya dalam ketentuan itu, ketika perusahaan dinyatakan pailit, pembayaran upah untuk pekerja tidak didahulukan. Yang diprioritaskan malah utang negara dan biaya kurator, kreditor separatis pemegang jaminan gadai, fidusia, dan atau hak tanggungan (HukumOnline).

Kata -didahulukan pembayaranyall pada pasal 95 ayat (4) Undang-undang Ketenagakerjaan berpotensi menimbulkan ketidakpastian hukum karena tidak adanya penafsiran yang jelas dan tegas sehingga menimbulkan pertentangan dengan pasal 28D ayat (1) UUD 1945 yang menjamin akan adanya suatu kepastian hukum yang menyatakan:-Setiap orang berhak atas pengakuan, jaminan, perlindungan, dan kepastian hukum yang adil serta perlakuan yang sama di hadapan hukum."

Pada tanggal 11 September 2014, Mahkamah Konstitusi menjatuhkan putusan dalam perkara Pengujian Undangundang Nomor 13 tahun 2003 tentang Ketenagakerjaan terhadap Undang-undang Dasar Negara Republik Indonesia, yang memutuskan bahwa sesuai dengan pasal 95 ayat (4) kedudukan upah dalam perusahaan pailit, sebagai berikut:

a) Tidak bertentangan dengan Undang-undang Dasar 1945 apabila Upah didahulukan atas semua jenis kreditur, jadi posisi upah berada diatas kreditur separatis, tagihan hak negara, kantor lelang dan badan hukum yang dibentuk Pemerintah.

b) Mempunyai kekuatan hukum yang mengikat apabila Upah didahulukan atas semua jenis kreditur, jadi posisi upah berada diatas kreditur separatis, tagihan hak negara, kantor lelang dan badan hukum yang dibentuk Pemerintah

Buruh mendapat perlindungan dan kepastian hukum terhadap hak atas upah maupun hak-hak lainnya dalam keadaan perusahaan pailit. Putusan Mahkamah Konstitusi tersebut, sudah jelas apabila terjadi kepailitan, hak mendahulu atas utang pajak tidak berlaku apabila bertemu dengan upah pekerja/buruh dan hak-hak pekerja buruh/ lainnya. Hal ini agak berbeda dengan kreditor separatis dimana, jika ada pembayaran upah pekerja/buru maka kreditor separatis mengalah tapi tidak untuk pembayaran hak-hak pekerja/ buruh lainnya.

Pertimbangan Majelis Hakim memutus demikian adalah upah pekerja/buruh secara konstitusional berdasarkan Pasal 28D ayat (2) UUD 1945 merupakan hak konstitusional yang oleh karenanya adalah hak konstitusional pula untuk mendapat perlakuan yang adil dan layak dalam hubungan kerja. Sedangkan mengenai kewajiban/ tagihan terhadap negara, adalah wajar jika berada diperingkat setelah upah dan hak-hak pekerja/ buruh (seperti uang pesangon, uang 
penhargaan masa kerja dan uang penggantian hak dan seterusnya). Hal ini karena negara mempunyai sumber pembiayaan lain sedangkan bagi pekerja, upah adalah satu-satunya sumber mempertahankan hidup bagi diri dan keluarganya.

Putusan Mahkamah Konstitusi yang menempatkan upah pekerja sebagai prioritas pertama dari pembayaran dalam hal terjadi kepailitan, prioritas selanjutnya hak negara diharapkan kisruh antara upah buruh dan utang pajak berakhir. Hak-hak lainnya, yakni hak yang timbul dalam hubungan kerja atau sebagai akibat dari hubungan kerja merupakan hak yang diistimewakan saja yang diberikan keistimewaannya oleh Undang-undang untuk mendahului para kreditor konkuren lainnya.

Hak-hak lain pekerja atau buruh tidak sama atau tidak setara dengan upah, sehingga pada pelunasan hak-hak lain buruh wajar bila berada di posisi setelah kreditor separatis. Menurut Mahkamah, hak-hak pekerja/buruh yang lainnya adalah tidak sama atau berbeda dengan upah pekerja/buruh. Upah pekerja/buruh secara konstitusional berdasarkan Pasal 28D ayat (2) UUD 1945 merupakan hak konstitusional. Oleh karena itu, adalah hak konstitusional pula untuk mendapat perlakuan yang adil dan layak dalam hubungan kerja. Adapun hak-hak pekerja/buruh lainnya tidaklah demikian. Implikasi hukumnya adalah wajar bila terkait dengan pembayaran dimaksud hak tersebut berada pada peringkat di bawah kreditor separatis. Sementara itu, mengenai kewajiban terhadap negara hal tersebut adalah wajar manakala berada pada peringkat setelah upah pekerja/buruh. Argumentasinya antara lain adalah karena negara memiliki sumber pembiayaan lain. Sedangkan bagi pekerja/buruh upah adalah satu-satunya sumber untuk mempertahankan hidup bagi diri dan keluarganya.

Pada tanggal 11 September 2014, Mahkamah Konstitusi menjatuhkan putusan dalam perkara Pengujian Undangundang Nomor 13 tahun 2003 tentang Ketenagakerjaan terhadap Undang-undang Dasar Negara Republik Indonesia, yang memutuskan bahwa sesuai dengan pasal 95 ayat (4) kedudukan upah dalam perusahaan pailit, sebagai berikut:

a) Tidak bertentangan dengan Undang-undang Dasar 1945 apabila pembayaran hak-hak pekerja atau buruh lainnya didahulukan atas semua tagihan termasuk tagihan hak negara, kantor lelang, dan badan umum yang dibentuk Pemerintah, kecuali tagihan dari kreditor separatis.

b) Mempunyai kekuatan hukum yang mengikat apabila pembayaran hak-hak pekerja/buruh lainnya didahulukan atas semua tagihan termasuk tagihan hak negara, kantor lelang, dan badan umum yang dibentuk Pemerintah, kecuali tagihan kreditor separatis.

\section{Penutup}

Sebelum adanya Putusan Mahkamah Konstitusi Nomor 67/PUU-XI/2013 pembayaran upah kerap berada di posisi setelah kreditor separatis, pembayaran utang pajak, penggantian polis asuransi dan hak tanggungan namun setelah adanya Putusan Mahkamah Konstitusi Nomor 67/PUU-XI/2013 upah pekerja atau buruh harus didahulukan dalam kasus kepailitan suatu perusahaan dan tidak lagi berada diposisi ketiga setelah utang tagihan negara maupun kreditor separatis, melainkan naik menempati urutan pertama. Sehingga pada praktiknya apabila suatu perusahaan diputuskan pailit, maka perusahaan tersebut terlebih dahulu membayar hak upah pekerja atau buruhnya yang terutang.

Kedudukan hak-hak lain pekerja atau buruh dengan adanya Putusan Mahkamah Konstitusi Nomor 67/PUU-XI/2013 didahulukan atas tagihan hak negara, kantor lelang, dan badan umum yang dibentuk Pemerintah. Tetapi kedudukan hak-hak lain pekerja atau buruh masih berada di bawah tagihan hak upah dan kreditur separatis. Sehingga pada praktiknya apabila suatu perusahaan diputuskan pailit, maka hak-hak lain pekerja atau buruh berada di posisi ketiga setelah pelunasan hak upah dan tagihan kreditur separatis.

\section{References}

[1] Jono, Hukum Kepailitan, Sinar Grafika, Jakarta, 2008.

[2] Marzuki, Peter Mahmud, Penelitian Hukum, Kencana, Jakarta,.

[3] 2005 Mahkamah Konstitusi , Putusan Nomor 67/PUU-XI/2013.

[4] Suryahadi, A., Widyanti, W. P., Sumarto, S. 2003. Minimum Wage Policy and Its Implication on Employment in the Urban Formal Sector. Bulletin of Indonesian Economic Studies.

[5] Usman, Rachmadi, Dimensi Hukum Kepailitan di Indonesia. PT. Gramedia Pustaka Utama, Jakarta, 2004.

[6] Yani, Ahmad \& Gunawan Widjaja, Seri Hukum Bisnis: Kepailitan, PT RajaGrafindo Persada, Jakarta, 1999. 
[7] Billy Lumowa, Ardy, Tanggung Jawab Perusahaan Yang Dinyatakan Pailit Terhadap Pihak Ketiga, http://ejournal.unsrat.ac.id/index.php/lexprivatum/article/viewFile/3034/2579,

[8] Republik Indonesia, Undang-undang Nomor 13 tahun 2003 tentang Ketenagakerjaan, LN Tahun 2003 Nomor 39 , ps.95 (4).

[9] Republik Indonesia, Undang-undang Nomor 37 Tahun 2004 Tentang Kepailitan dan Penundaan Kewajiban, LN Tahun 2004 No. 13.

[10] http://ksbsi-sumsel.blogspot.co.id/?view=sidebar.

[11] http://www.hukumonline.com/berita/baca/lt5412a9f00ba43/upah-buruh-harus-didahulukan-dalam-kepailitan.

[12] http://www.bppk.kemenkeu.go.id/publikasi/artikel/167-artikel-pajak/20492-upah-buruh-vs-utang-pajak,mana-yang-didahulukanpembayarannya.

[13] http://www.bppk.kemenkeu.go.id/publikasi/artikel/167-artikel-pajak/20492-upah-buruh-vs-utang-pajak,mana-yang-didahulukanpembayarannya.

[14] http://elmahkamah.blogspot.co.id/2014/10/perusahaan-pailit-harus-dahulukan-upah.html. 